attempts over the past three years had to be cancelled when the Discovery broke down.

The new vessel would not only have replaced the Discovery but would also have incorporated twenty-first-century technology, such as mini-thrusters, which would allow the ship to remain in a precise position for sampling a water column. And she would have featured multibeam swath bathymetry, an acoustic technique used to produce depth and other maps, together with instruments central to geophysical and other research that are lacking on the Discovery.

Speaking on behalf of NERC, Edward Hill, director of the National Oceanography Centre in Southampton, puts a brave face on the government's decision. "It's a disappointment," he says, although he notes that it's a postponement, not an outright cancellation.

To make the high costs of research ships more palatable to governments, scientists in the 1990s touted the idea of sharing the cost of building new research vessels by making them European instead of national. In 1996, Britain, France and

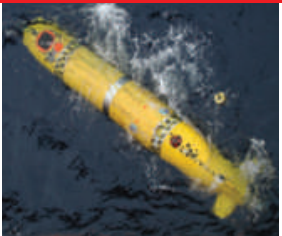

TRAPPED UNDER ICE

Risky submarine mission maps the underside of an Antarctic glacier.

www.nature.com/news
Germany agreed to barter ship time on each other's vessels as a first step towards this goal. The Netherlands, Norway and Spain have since joined them. Ironically, the scheme has proved so successful that the goal of a pan-European fleet has all but been abandoned. But bartering time on other countries' ships demands having something to barter with, notes Wolff. "The UK is rapidly running out of barter credit, and this decision to postpone its new ship has diminished it even further."

Declan Butler

\title{
Canadian science minister under fire
}

It's been a rough month for Canada's minister of science and technology. Gary Goodyear, who was appointed to the new position in October 2008, has been roundly criticized in the media for an outburst during a meeting with a university teachers' group and for his comments on evolution.

Some Canadian researchers say the criticism is unreasonable, but others say it suggests that Goodyear, a chiropractor by training, is not in tune with the community whose portfolio he oversees.

In early March, the Torontobased Globe and Mail reported that Goodyear had stormed out of a meeting with two officials from the Canadian Association of University Teachers (CAUT), a lobby group representing 65,000 academic staff at 121 universities and colleges. The spat erupted over the group's concerns about the 2009 budget, which gave investments in university infrastructure priority over operational research funding (see Nature $457,646 ; 2009)$. Some argue that the government is emphasizing the commercialization of science at the expense of basic research.

Then on 17 March, Goodyear's scientific credentials were called into question by the

headline "Minister won't confirm belief in evolution". According to the Globe and Mail, when asked whether he believed in evolution, Goodyear responded, "I'm not going to answer that question. I am a Christian, and I don't think anybody asking a question about my religion is appropriate". During a later interview on television, Goodyear declared that he does accept evolution and added that he didn't answer the question because "it wasn't relevant to the portfolio" and that the "focus should be on the economy and creating jobs".

Some scientists say the flap over evolution

"Canadians can rightly question the technical competence of elected officials." is unfortunate. Many couldn't care less about his personal beliefs. "As a professional he would never allow his religion to come into play in work. We all expect that level of professionalism," says Ryan MacKay, scientific director of the National High Field Nuclear Magnetic Resonance Centre in Edmonton, Alberta.

But others were disturbed by the words Goodyear used in the television interview. "We are evolving every year, every decade," he said. "That's a fact, whether it's to the intensity of the sun ... or to the effects of walking on concrete. Of course, we are evolving to our environment."

"Canadians can rightly question the technical competence of elected officials," says Robert Wolkow, a nanoscience expert and physicist at the University of Alberta in Edmonton. "Just as we would expect an agriculture minister to know a heifer from a $\mathrm{hog}$, it's reasonable for a science minister to know established scientific basics," he said. Goodyear was unavailable for comment for this article.

Goodyear reports to parliament on the activities of the Natural Sciences and Engineering Research Council (NSERC) and the Canadian Institutes of Health Research (CIHR) and is responsible for their budgets, although grants are determined by peer review. He is also in charge of implementing the Science and Technology Strategy, which was released in May 2007.

At this point no one seems interested in calling for Goodyear's resignation. James Turk, executive director of the CAUT, says that the question is not whether Goodyear should be replaced but whether the government will commit to investing in research. "We need the government to match what the Obama government is doing for research," he argues.

The 2009 federal budget has been widely criticized by the research community. Much of the worry has centred on its effects on the three granting councils - the NSERC, CIHR and the Social Sciences and Humanities Research Council - which were told to scale back their collective budget by Can $\$ 147.9$ million (US\$120 million) over three years.

"It's a significant concern for those of us who believe that curiosity-driven research will, over time, lead to major breakthroughs," says Dick Peltier, a physicist and the director of the Centre for Global Change Science at the University of Toronto. "It's a short-term mindset that is not in accord with the historical evolution of ideas, and it is a terrible mistake."

Hannah Hoag 